\title{
Molecular interaction of bioactive compounds from Senecio biafrae leaf with a-amylase and a-glucosidase receptors
}

\author{
Basiru Olaitan Ajiboye (D)
}

\begin{abstract}
Background: Diabetes mellitus is one of the silent killer diseases affecting millions of people globally and some of the key enzymes in managing this disease are a-amylase and a-glucosidase This study was designed to investigate the possible molecular interactions between various bioactive compounds of Senecio biafrae leaf on a-amylase and a-glucosidase (enzymes) receptors an important target protein in Type 2 diabetes mellitus.
\end{abstract}

Methods: This study involved the investigation of the of gallic acid, chlorogenic, caffeic acid, rutin, quercetin, and kaempferol (ligands) for Lipinski's rule of five using Molinspiration, ADMET profiles using admetSAR server and molecular docking of 3D structures of the six bioactive compounds and metformin against a-amylase and aglucosidase were carried out using AutoDockVina.

Results: The results revealed that caffeic acid, quercetin, and kaempferol obey Lipinski's rule of five. All the ligands demonstrated high gastrointestinal tract absorption except rutin and chlorogenic acid, only one can serve as a Pglycoprotein substrate and three of the ligands used can act as cytochrome P450 inhibitors isoforms. All the ligands had a high binding affinity than metformin (the standard drug used).

Conclusion: In can be concluded that some of the bioactive compounds (especially caffeic acid) in Senecio biafrae leaf have antidiabetic activity, which they may serve as a potential antidiabetic drug in the management of diabetes mellitus than metformin.

Keywords: Senecio biafrae leaf, a-Amylase, a-Glucosidase, Receptors, Bioactive compounds

\section{Introduction}

Type 2 diabetes mellitus (T2DM) has been known with hyperglycaemia, which can lead to series of health complications like nephropathy, neuropathy, retinopathy, and cardiovascular disease [6]. Alqahtani et al. [7] documented that T2DM is one of the health diseases and accounting for more than $90 \%$ incidence of diabetes mellitus globally.

The main therapeutic method of managing postprandial hyperglycaemia in T2DM is by inhibiting the digestion of nutritional carbohydrates [5]. Furthermore,

\section{Correspondence: bash1428@yahoo.co.uk}

Phytomedicine and Molecular Toxicology Research Laboratory,Department of Biochemistry, Faculty of Science, Federal University Oye-Ekiti, Ekiti State, Nigeria pancreatic $\alpha$-amylase is the main enzyme involves in breaking down nutritional polysaccharides into disaccharides and by another important enzyme known as $\alpha$ glucosidases to monosaccharides (e.g. glucose), which can be absorbed into the bloodstream. $\alpha$-glucosidase is an enzyme found in the brush border of the small intestine epithelium [12]. Hence, inhibiting $\alpha$-amylase and $\alpha$ glucosidase enzymes can help in retarding nutritional carbohydrate digestion and glucose uptake [20].

Currently, there are several conventional drugs available in managing T2DM, these include acarbose, voglibose, and miglitol but these are characterized by different side effects [10]. Therefore, it is believed that bioactive compounds from medicinal plants are known with little or no side effects [24], an example of such a

\section{Springer Open}

(c) The Author(s). 2022 Open Access This article is licensed under a Creative Commons Attribution 4.0 International License, which permits use, sharing, adaptation, distribution and reproduction in any medium or format, as long as you give appropriate credit to the original author(s) and the source, provide a link to the Creative Commons licence, and indicate if changes were made. The images or other third party material in this article are included in the article's Creative Commons licence, unless indicated otherwise in a credit line to the material. If material is not included in the article's Creative Commons licence and your intended use is not permitted by statutory regulation or exceeds the permitted use, you will need to obtain permission directly from the copyright holder. To view a copy of this licence, visit http://creativecommons.org/licenses/by/4.0/. 
Table 1 Bioactive compounds identified in Senecio biafrae leaf

\begin{tabular}{|c|c|c|c|c|c|c|}
\hline S/No & $\begin{array}{l}\text { Compound } \\
\text { Name }\end{array}$ & $\begin{array}{l}\text { Chemical } \\
\text { Class }\end{array}$ & $\begin{array}{l}\text { Compound } \\
\text { PubChem } \\
\text { ID }\end{array}$ & $\begin{array}{l}\text { Molecular } \\
\text { formular }\end{array}$ & SMILE & Chemical structure \\
\hline 1 & Gallic acid & Phenol & CID 370 & $\underline{\mathrm{C}_{7}} \mathrm{H}_{6} \mathrm{O}_{5}$ & $\begin{array}{l}\mathrm{C} 1=\mathrm{C}(\mathrm{C}=\mathrm{C}(\mathrm{C}(=\mathrm{C} 1 \mathrm{O}) \mathrm{O}) \\
\mathrm{O}) \mathrm{C}(=\mathrm{O}) \mathrm{O}\end{array}$ & \\
\hline 2 & $\begin{array}{l}\text { Chlorogenic } \\
\text { acid }\end{array}$ & Phenol & $\begin{array}{l}\text { CID } \\
1794427\end{array}$ & $\underline{\mathrm{C}}_{16} \underline{\mathrm{H}}_{18} \underline{\mathrm{O}}_{9}$ & $\begin{array}{l}\mathrm{C} 1 \mathrm{C}(\mathrm{C}(\mathrm{C}(\mathrm{CC} 1(\mathrm{C}(=\mathrm{O}) \mathrm{O}) \\
\mathrm{O}) \mathrm{OC}(=\mathrm{O}) \mathrm{C}=\mathrm{CC} 2=\mathrm{CC}(= \\
\mathrm{C}(\mathrm{C}=\mathrm{C} 2) \mathrm{O}) \mathrm{O}) \mathrm{O}) \mathrm{O}\end{array}$ & \\
\hline 3 & Caffeic acid & Phenol & CID 689043 & $\underline{\mathrm{C}}_{9} \underline{\mathrm{H}}_{8} \underline{\mathrm{O}}_{4}$ & $\begin{array}{l}\mathrm{C} 1=\mathrm{CC}(=\mathrm{C}(\mathrm{C}=\mathrm{C} 1 \mathrm{C}=\mathrm{CC}( \\
=\mathrm{O}) \mathrm{O}) \mathrm{O}) \mathrm{O}\end{array}$ & \\
\hline 4 & Rutin & Flavonoid & $\begin{array}{l}\text { CID } \\
5280805\end{array}$ & $\underline{\mathrm{C}}_{27} \underline{\mathrm{H}}_{30} \underline{\mathrm{O}}_{16}$ & $\begin{array}{l}\mathrm{CC} 1 \mathrm{C}(\mathrm{C}(\mathrm{C}(\mathrm{C}(\mathrm{O} 1) \mathrm{OCC} 2 \\
\mathrm{C}(\mathrm{C}(\mathrm{C}(\mathrm{C}(\mathrm{O} 2) \mathrm{OC} 3=\mathrm{C}(\mathrm{O} \\
\mathrm{C} 4=\mathrm{CC}(=\mathrm{CC}(=\mathrm{C} 4 \mathrm{C} 3=\mathrm{O}) \\
\mathrm{O}) \mathrm{O}) \mathrm{C} 5=\mathrm{CC}(=\mathrm{C}(\mathrm{C}=\mathrm{C} 5) \\
\mathrm{O}) \mathrm{O}) \mathrm{O}) \mathrm{O}) \mathrm{O}) \mathrm{O}) \mathrm{O}) \mathrm{O}\end{array}$ & \\
\hline 5 & Quercetin & Flavonoid & $\begin{array}{l}\text { CID } \\
5280343\end{array}$ & $\underline{\mathrm{C}}_{15} \underline{\mathrm{H}}_{10} \underline{\mathrm{O}}_{7}$ & $\begin{array}{l}\mathrm{C} 1=\mathrm{CC}(=\mathrm{C}(\mathrm{C}=\mathrm{C} 1 \mathrm{C} 2=\mathrm{C}( \\
\mathrm{C}(=\mathrm{O}) \mathrm{C} 3=\mathrm{C}(\mathrm{C}=\mathrm{C}(\mathrm{C}=\mathrm{C} 3 \\
\mathrm{O} 2) \mathrm{O}) \mathrm{O}) \mathrm{O}) \mathrm{O}) \mathrm{O}\end{array}$ & \\
\hline 6 & Kaempferol & Flavonoid & $\begin{array}{l}\text { CID } \\
5280863\end{array}$ & $\underline{\mathrm{C}}_{15} \underline{\mathrm{H}}_{10} \underline{\mathrm{O}}_{6}$ & $\begin{array}{l}\mathrm{C} 1=\mathrm{CC}(=\mathrm{CC}=\mathrm{C} 1 \mathrm{C} 2=\mathrm{C}( \\
\mathrm{C}(=\mathrm{O}) \mathrm{C} 3=\mathrm{C}(\mathrm{C}=\mathrm{C}(\mathrm{C}=\mathrm{C} 3 \\
\mathrm{O} 2) \mathrm{O}) \mathrm{O}) \mathrm{O}) \mathrm{O}\end{array}$ & \\
\hline
\end{tabular}

plant is Senecio biafrae leaf as reported by Ajiboye et al. [5]. Senecio biafrae (local name Worowo in Yoruba speaking part of Nigeria) belongs to the group of vegetables that grow in large quantities as undercover in tree crop plantation. This leafy vegetable is also considered for its high medicinal value as the juice extracted from the leaf is wholly applied to fresh wounds or cuts as a styptic in the rural community for man and animal use [15]. It is one of the major green leafy vegetables consumed in Nigeria, Ghana, Benin, Sierra Leone, Cameroon and Gabon [5]. This plant leaf is endowed with medicinal properties [3]. Ajiboye et al. [4] documented the phytochemical constituents of the plant's leaf, with a high content of phenolic compounds. Because of this, in silico prediction of druggable phytochemicals from this plant leaf against $\alpha$-amylase and $\alpha$ glucosidases may be a breakthrough in designing a new drug in the management of diabetes mellitus.

\section{Methods}

Retrieval of bioactive compounds

Six bioactive compounds were gotten from a published article by Ajiboye et al. [5], and their chemical structures were reclaimed from PubChem (https://pubchem.ncbi. nlm.nih.gov/) database in SDF format, which was then

Table 2 Analysis of oral drug-likeness of the six bioactive compounds using Lipinski's rule of five

\begin{tabular}{llllll}
\hline Bioactive Compounds & $\begin{array}{l}\text { Molecular weight } \\
\text { (g/mol) }\end{array}$ & Log P & $\begin{array}{l}\text { Number of hydrogen } \\
\text { bond donor }\end{array}$ & $\begin{array}{l}\text { Number of hydrogen } \\
\text { bond acceptor }\end{array}$ & Molar refractivity \\
\hline Caffeic acid & 180.16 & 0.97 & 3 & 4 & 47.16 \\
Gallic acid & 170.12 & 0.21 & 4 & 5 & 38.47 \\
Metformin & 129.16 & 0.34 & 3 & 2 & 36.93 \\
Quercetin & 302.24 & 1.63 & 5 & 7 & 78.04 \\
Rutin & 617.66 & -92.39 & 10 & 14 & 147.66 \\
Chlorogenic acid & 354.31 & 0.87 & 6 & 9 & 83.50 \\
Kaempferol & 286.24 & 1.70 & 4 & 6 & 76.01 \\
\hline
\end{tabular}


Table 3 ADMET distribution profiles of the six bioactive compounds

\begin{tabular}{|c|c|c|c|c|c|c|c|c|}
\hline Bioactive compounds & G1 Absorption & BBB Permeability & P-gp Substrate & $\begin{array}{l}\text { CYP1A2 } \\
\text { Inhibitor }\end{array}$ & $\begin{array}{l}\text { CYP2C19 } \\
\text { Inhibitor }\end{array}$ & $\begin{array}{l}\text { CYP2C9 } \\
\text { Inhibitor }\end{array}$ & $\begin{array}{l}\text { CYP2D6 } \\
\text { Inhibitor }\end{array}$ & $\begin{array}{l}\text { CYP3A4 } \\
\text { Inhibitor }\end{array}$ \\
\hline Caffeic acid & High & No & No & No & No & No & No & No \\
\hline Gallic acid & High & No & No & No & No & No & No & Yes \\
\hline Metformin & High & No & No & No & No & No & No & No \\
\hline Quercetin & High & No & No & Yes & No & No & Yes & Yes \\
\hline Rutin & Low & No & Yes & No & No & No & No & No \\
\hline Chlorogenic acid & Low & No & No & No & No & No & No & No \\
\hline Kaempferol & High & No & No & Yes & No & No & Yes & Yes \\
\hline
\end{tabular}

converted into PDB format with the aid of Open Babel Converter (http://openbabel.org/wiki/Main_Page) [21].

\section{Examining the bioactive compounds for Lipinski's rule of five}

This rule assesses the drug-likeness of the six bioactive compounds using molinspiration cheminformatics tool. This includes the molecular weight of the bioactive compounds, Log P, number of hydrogen bond donors, number of hydrogen bond receptors, and molecular refractivity [17].

\section{ADMET prediction}

The absorption, distribution, metabolism, excretion, and toxicity (ADMET) were analyzed [18]. The study includes mutagenicity, toxicological dosage level as well as pharmacologically properties of each bioactive compounds, which were done using Swissadme (http://www. swissadme.ch) and admetSAR servers [11].

\section{Molecular docking}

The docking analyses of the six bioactive compounds and metformin (standard antidiabetic drug) with $\alpha$ amylase and $\alpha$-glucosidase were determined using AutoDockVina. The best complexes showing the highest score of molecular interactions between each ligand (bioactive compounds) with $\alpha$-amylase and $\alpha$ glucosidase enzymes used as receptors were selected. Also, PyMOL was used to view the amino acids of $\alpha$ - amylase and $\alpha$-glucosidase interacting with the inhibitors at active sites.

\section{Results}

\section{Selection of bioactive compounds}

The six bioactive compounds obtained from Senecio biafrae leaf used in this study, belong to two chemical classes (phenol and flavonoid) as indicated in Table 1.

\section{Analysis of Lipinski's rule of five}

In fulfilling the drug-likeness, molecules that have a molecular mass not greater than $500 \mathrm{Da}, \log \mathrm{P}$ not greater than 5, hydrogen bond donor not greater than 5, hydrogen bond acceptor not greater than 10, and molar refractivity between 40 to 130 . As illustrated in Table 2 only caffeic acid, quercetin and kaempferol obey this rule. Gallic acid, metformin, and chlorogenic acid slightly meet the criteria of this rule. Gallic acid and metformin have molar refractivity lower than 40 while chlorogenic acid has a number of hydrogen bonds above 5. On the other hand, rutin did not meet four of the Lipinski's rule of five.

\section{ADMET profiles}

As depicted in Table 3, all the bioactive compounds used in this study, as well as metformin, have high gastrointestinal tract (GIT) absorption except rutin and chlorogenic acid with low GIT absorption. All the six

Table 4 AutoDockVina results for each bioactive compound with their binding affinity against a-amylase and a-glucosidase

\begin{tabular}{llll}
\hline S/No & Bioactive Compounds & Binding affinity (Kcal/mol) against a-amylase & Binding affinity (Kcal/mol) against a-glucosidase \\
\hline 1 & Caffeic acid & -6.5 & -6.5 \\
2 & Chlorogenic acid & -7.2 & -8.3 \\
3 & Gallic acid & -5.4 & -6.1 \\
4 & Kaempferol & -8.1 & -8.5 \\
5 & Quercetin & -8.2 & -8.4 \\
6 & Rutin & -8.2 & -8.5 \\
7 & Metformin & -4.5 & -5.2 \\
\hline
\end{tabular}



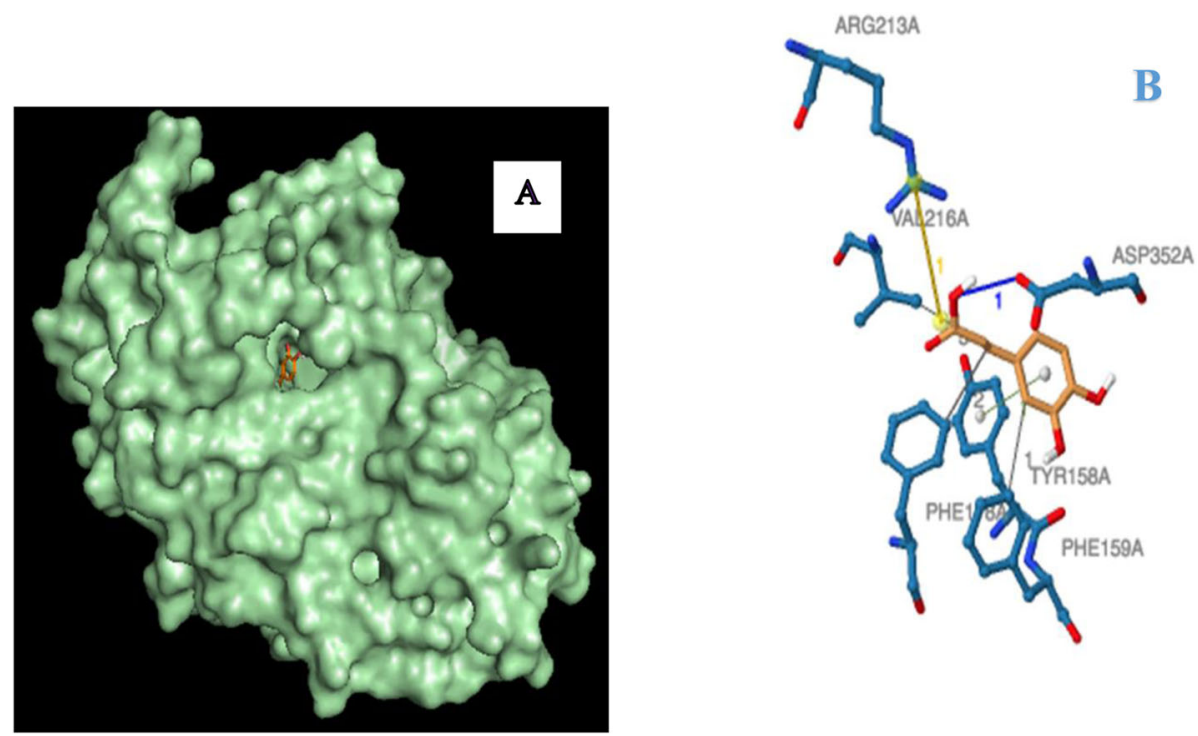

Fig. 1 Binding pose and binding site of caffeic acid with a-glucosidase (panel A), molecular interaction of caffeic acid with amino acid residues within the binding pocket of the protein structure (panel B)

bioactive compounds have no blood-brain barrier permeability, and only rutin can serve as the P-glycoprotein (P-gp) substrate. In another vein, all the six bioactive compounds and metformin (the standard used) are noninhibitors of cytochrome P450 isoforms, except quercetin which inhibits CYP1A2, CYP2D6, and CYP3A4; gallic acid inhibits CYP3A4; and kaempferol inhibits CYP1A2, CYP2D6, and CYP3A4.

\section{Molecular docking and binding energy analysis}

The binding activity of $\alpha$-amylase and $\alpha$-glucosidase are shown in Table 4 with all the six bioactive compounds having a higher binding affinity than the standard drug used. In $\alpha$-amylase, rutin and quercetin have the highest binding affinity of $-8.2 \mathrm{kcal} / \mathrm{mol}$ while in $\alpha$-glucosidase, rutin and kaempferol have the highest binding affinity of $-8.5 \mathrm{kcal} / \mathrm{mol}$. Figures $1,2,3,4,5,6,7,8,9,10,11$ and 12 shows the binding pose of each ligand with their receptors as well as their molecular interactions with different amino acid residues within the binding pocket of the protein structure. All the ligands form hydrophobic interaction, hydrogen bond, and $\pi$ stacking with both of $\alpha$-amylase and $\alpha$-glucosidase using different amino acids (Tables 5, 6, 7, 8, 9, 10, 11, 12, 13, 14, 15, 16, 17 and 18).
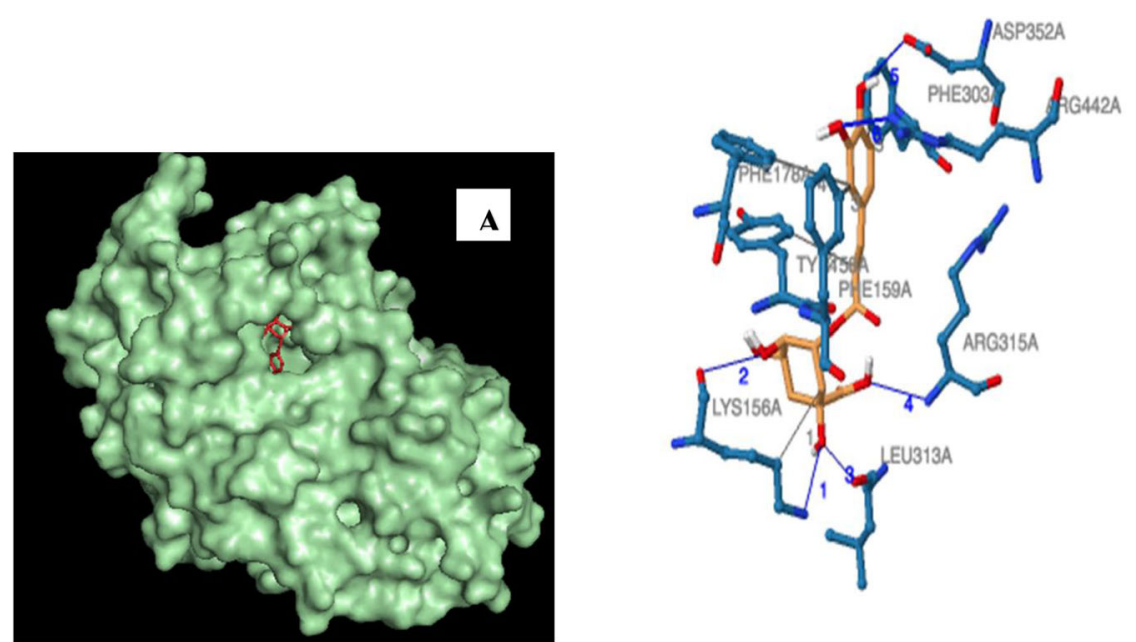

Fig. 2 Binding pose and binding site of chlorogenic acid with a-glucosidase (panel A), molecular interaction of chlorogenic acid with amino acid residues within the binding pocket of the protein structure (panel B) 

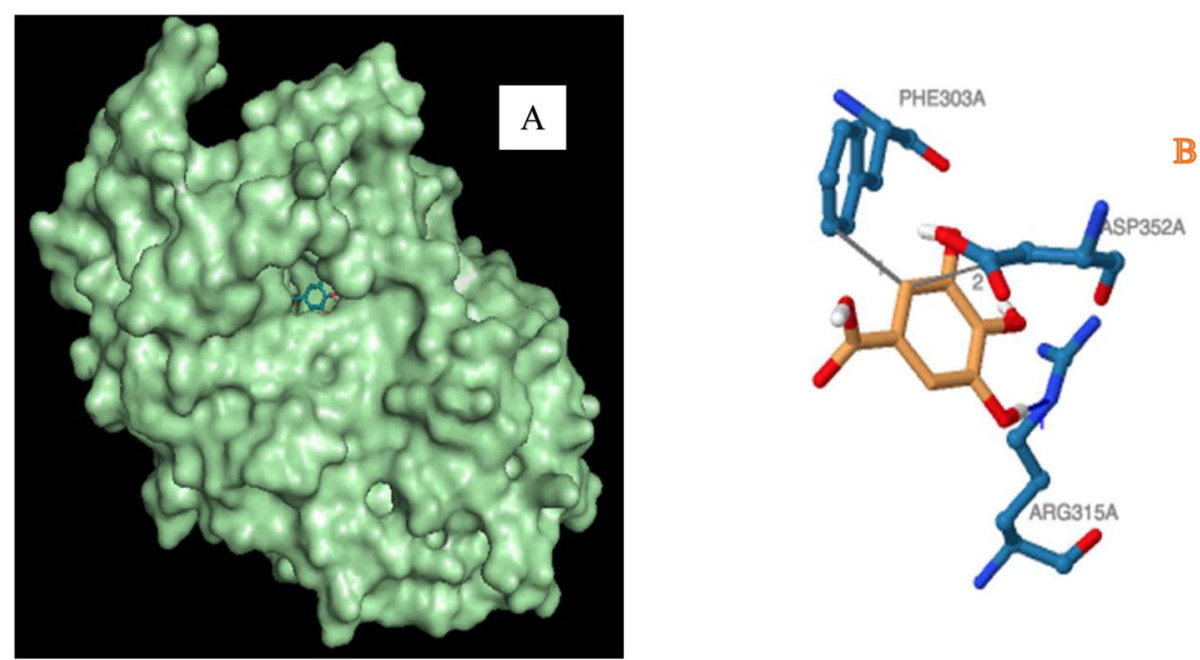

Fig. 3 Binding pose and binding site of gallic acid with a-glucosidase (panel A), molecular interaction of gallic acid with amino acid residues within the binding pocket of the protein structure (panel B)

\section{Discussion}

The present study was designed to investigate the in silico molecular interaction of bioactive compounds from Senecio biafrae with key enzymes related to diabetes mellitus. Diabetes mellitus (DM) is a metabolic disorder with increasing prevalence all over the world. According to Li and Ding [16], there were approximately 366 million people suffered from DM (aged 20-79 years) in 2011 and this figure would climb up to 552 million by the year 2030. DM is characterized by hyperglycemia as well as the development of diabetes-specific complications. These complications can result in disastrous consequences, but many synthetic drugs used today failed to complete long-term glycemic control [22]. Clinically, novel treatments with fewer side effects are desirable for the control of DM as well as its complications.
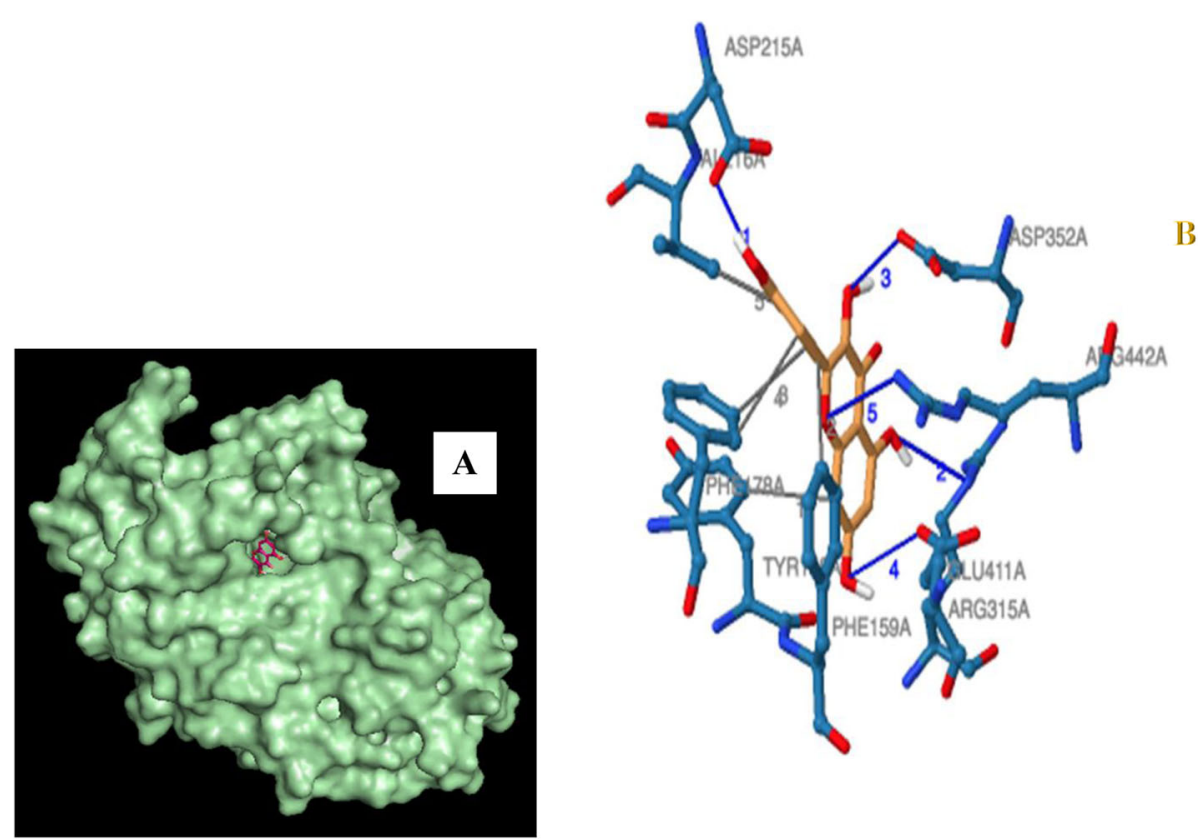

Fig. 4 Binding pose and binding site of kaempferol with a-glucosidase (panel A), molecular interaction of kaempferol with amino acid residues within the binding pocket of the protein structure (panel B) 

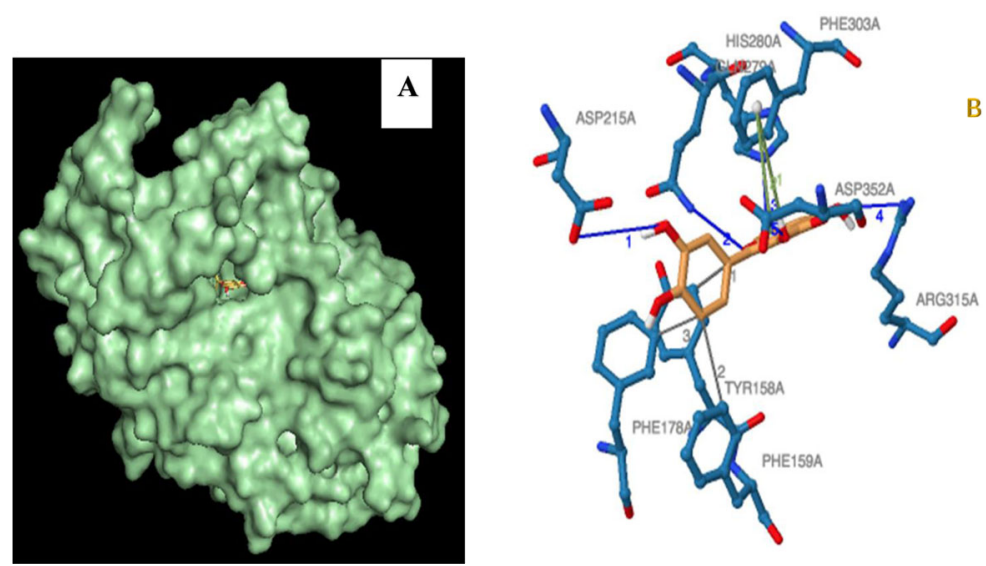

Fig. 5 Binding pose and binding site of quercetin with a-glucosidase (panel A), molecular interaction of quercetin with amino acid residues within the binding pocket of the protein structure (panel B)
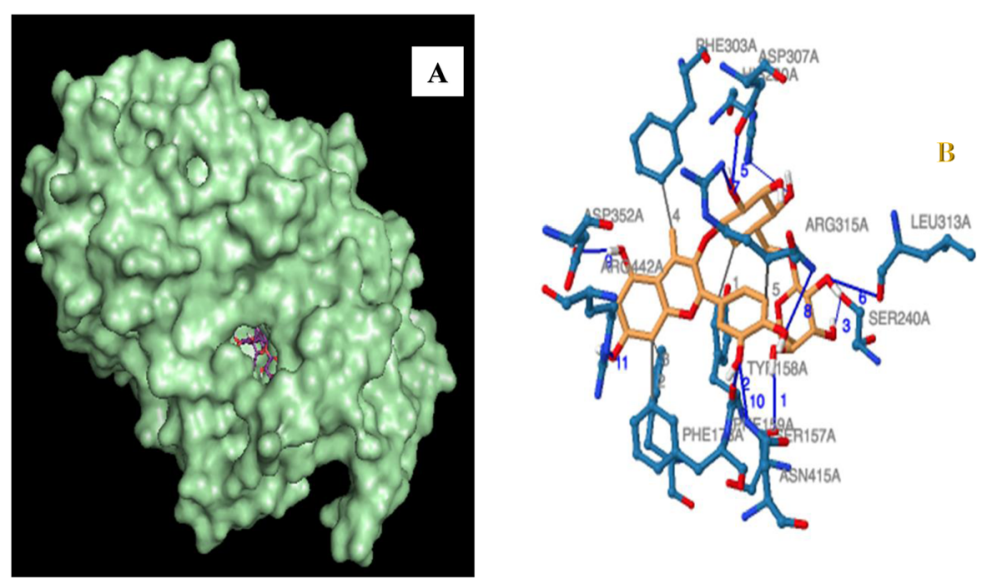

Fig. 6 Binding pose and binding site of rutin with a -glucosidase (panel A), molecular interaction of rutin with amino acid residues within the binding pocket of the protein structure (panel B)
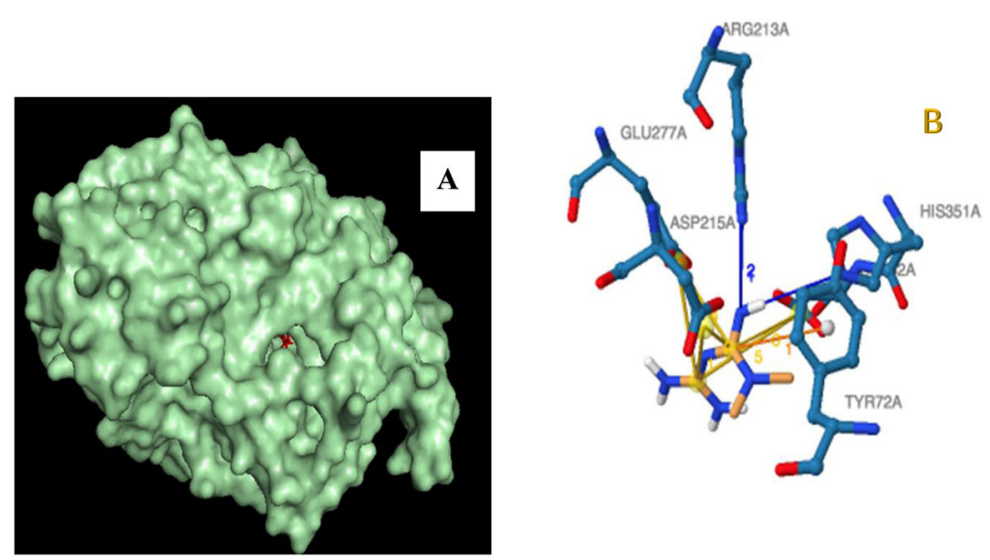

Fig. 7 Binding pose and binding site of metformin with a-glucosidase (panel A), molecular interaction of metformin with amino acid residues within the binding pocket of the protein structure (panel B) 

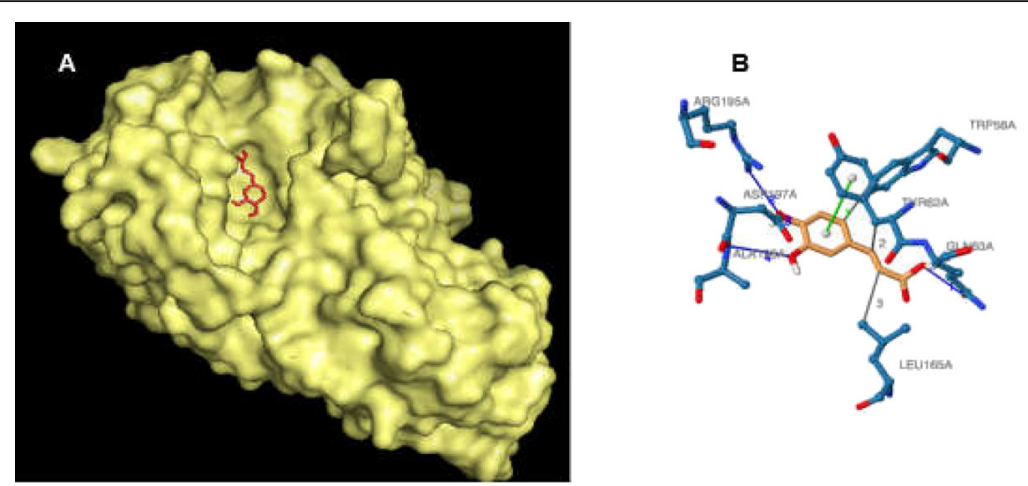

Fig. 8 Binding pose and binding site of caffeic acid with alpha amylase (panel A), molecular interaction of caffeic acid with amino acid residues within the binding pocket of the protein structure (panel B)
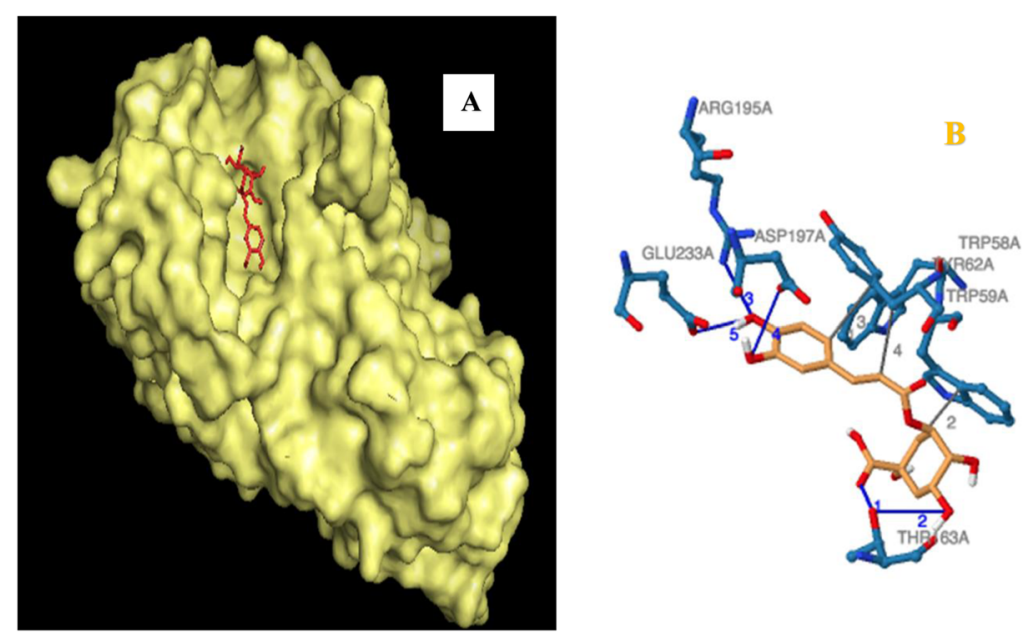

Fig. 9 Binding pose and binding site of chlorogenic acid with a- amylase (panel A), molecular interaction of chlorogenic acid with amino acid residues within the binding pocket of the protein structure (panel B)
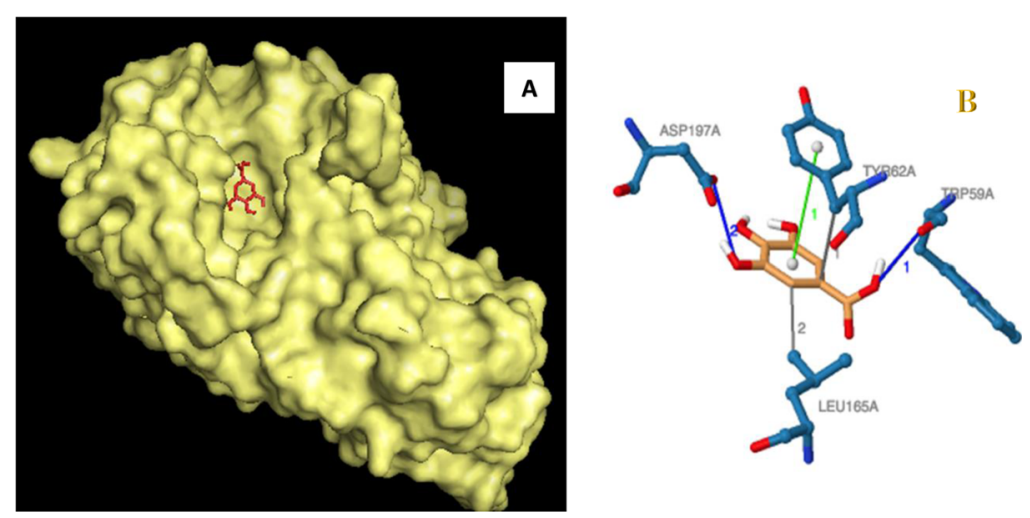

Fig. 10 Binding pose and binding site of gallic acid with a-amylase (panel A), molecular interaction of gallic acid with amino acid residues within the binding pocket of the protein structure (panel B) 

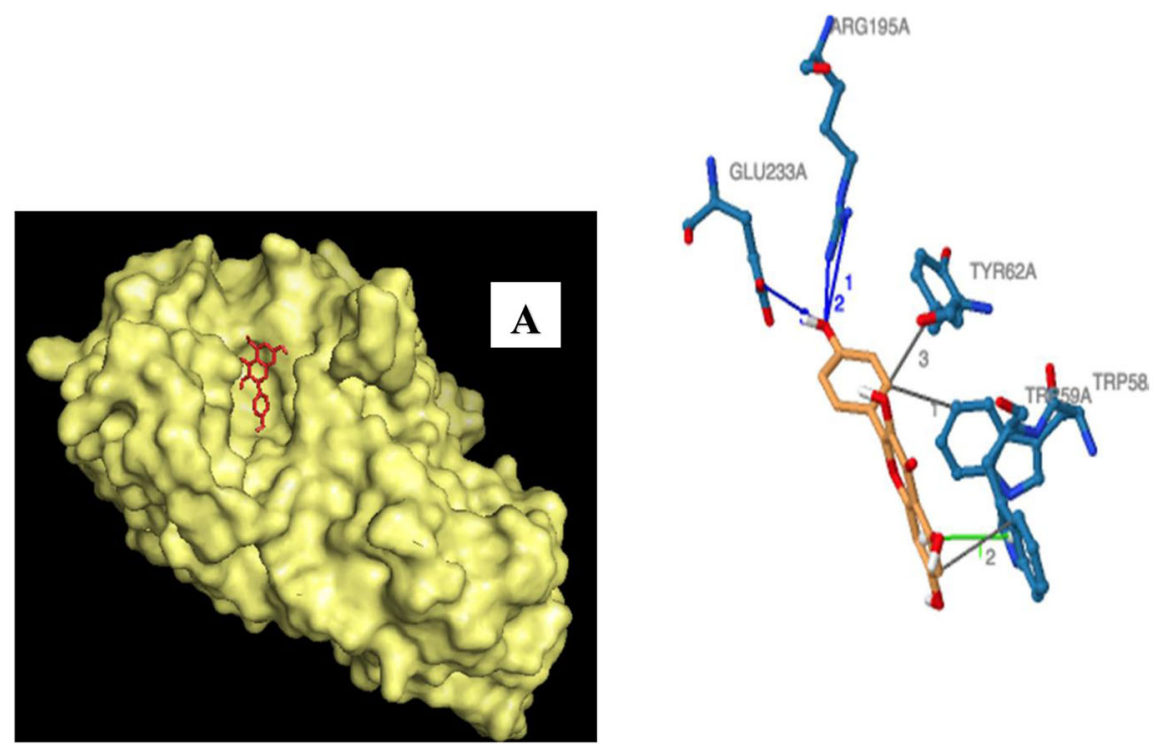

Fig. 11 Binding pose and binding site of kaempferol with a-amylase (panel A), molecular interaction of kaempferol with amino acid residues within the binding pocket of the protein structure (panel B)

Interestingly, the use of plant extracts that possess widespread biological functions has increased in recent years $[16,22]$.

According to Oboh [19], the phenolic constituent of plants endowed with antioxidants capable of scavenging free radicals produced in the body. The presence of flavonoids and phenolics (gallic acid, chlorogenic, caffeic acid, rutin, quercetin, and kaempferol) in Senecio biafrae may also contribute to lowering cellular oxidative stress and inhibit $\alpha$-amylase, and $\alpha$-glucosidase activities among others [1]. The uses of the phenolic extract of $S$. biafrae leaf in vitro in the management of type II diabetes mellitus are scanty in the literature.
Alpha-glucosidase is a glucosidase located in the brush border of the small intestine that acts upon $\alpha(1 \rightarrow 4)$ bonds [8]. Alpha-glucosidase breaks down starch and disaccharides to glucose. Alpha-glucosidase inhibitor competitively and reversibly inhibits alpha-glucosidase in the intestines. This inhibition lowers the rate of glucose absorption through delayed carbohydrate digestion and extended digestion time [23]. Hence, alpha-glucosidase as well as alpha-amylase (found in the salivary gland) inhibitors are used as anti-diabetic drugs in combination with other anti-diabetic drugs.

As demonstrated in Table 2, caffeic acid, quercetin, and kaempferol obey Lipinski's rule of five or Pfizer's
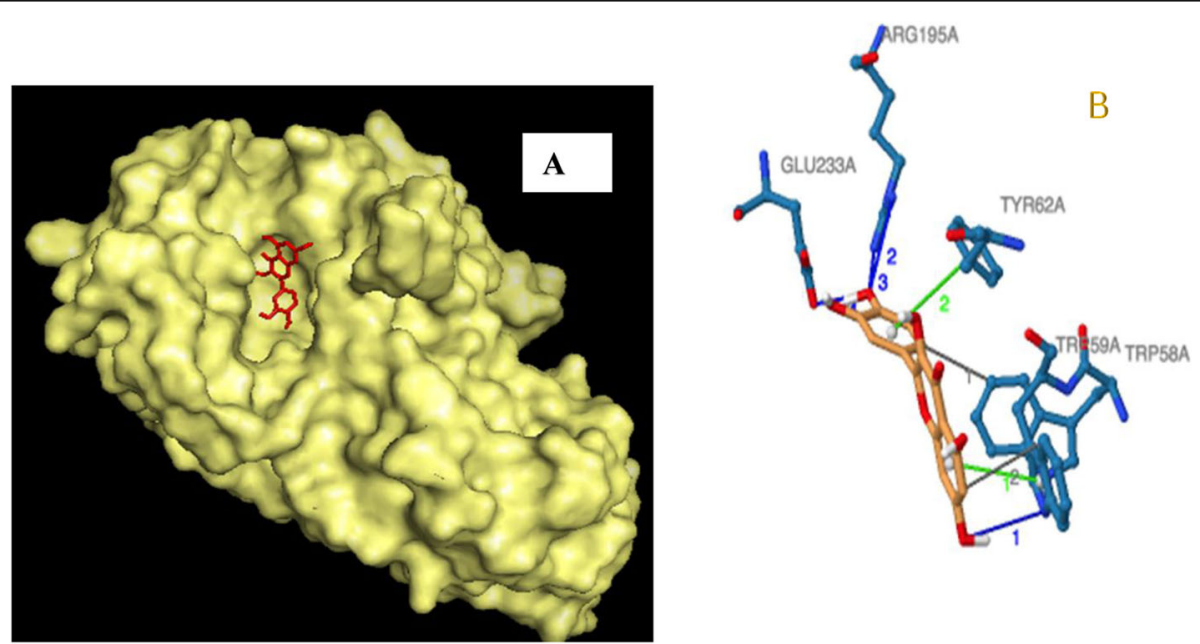

Fig. 12 Binding pose and binding site of quercetin with a-amylase (panel A), molecular interaction of quercetin with amino acid residues within the binding pocket of the protein structure (panel B) 
Table 5 Hydrogen bonding and hydrophobic interactions between caffeic acid and amino acid residues within a-glucosidase binding site

\begin{tabular}{l|llllll|}
\hline Hydrophobic Interactions ..... \\
\begin{tabular}{|llllll|}
\hline Index & Residue & AA & Distance & Ligand Atom & Protein Atom \\
\hline 1 & $159 \mathrm{~A}$ & PHE & 3.96 & 4838 & 1296 \\
\hline 2 & $178 \mathrm{~A}$ & PHE & 3.61 & 4843 & 1459 \\
\hline 3 & $216 \mathrm{~A}$ & VAL & 3.93 & 4843 & 1769 \\
\hline
\end{tabular}
\end{tabular}

\begin{tabular}{|c|c|c|c|c|c|c|c|c|c|}
\hline Index & Residue & AA & Distance H-A & Distance D-A & Donor Angle & Protein donor? & Sidechain & Donor Atom & Acceptor Atom \\
\hline 1 & $352 \mathrm{~A}$ & ASP & 2.31 & 3.15 & 143.42 & $x$ & $\nu$ & 4847 [O.co2] & $2885[0 . c 02]$ \\
\hline
\end{tabular}

II-Stacking........

\begin{tabular}{|llllllll||}
\hline \hline Index & Residue & AA & Distance & Angle & Offset & Type & Ligand Atoms \\
\hline 1 & $158 \mathrm{~A}$ & TYR & 4.88 & 69.65 & 0.81 & T & $4837,4838,4839,4840,4841,4842$ \\
\hline
\end{tabular}

Salt Bridges ....

\begin{tabular}{|lllllll|}
\hline \hline Index & Residue & AA & Distance & Protein positive? & Ligand Group & Ligand Atoms \\
\hline 1 & $213 A$ & ARG & 5.27 & & Carboxylate & 4846,4847 \\
\hline
\end{tabular}

rule, which is one of the techniques normally employed in assessing the drug-likeness of a chemical compound. This rule gives a clue if a chemical compound possesses pharmacological properties that may be plausible as an oral drug for humans or not $[17,21]$. This implies that caffeic acid, quercetin, and kaempferol may serve as potential drugs in the management of diabetes mellitus and probably better than metformin.

Caffeic acid, gallic acid, quercetin, and kaempferol have high absorption in the human gastrointestinal tract
(Table 3). This means that these bioactive compounds can be easily metabolized in the human body system. Also, according to Daneman and Prat [9], the bloodbrain barrier (BBB) is a selective semipermeable border of endothelial cells that inhibits solutes in the circulating blood from crossing into the extracellular fluid of the central nervous system where neurons reside. The blood-brain barrier is formed by endothelial cells and permits the passage of some molecules by passive diffusion and selective transport of different nutrients, ions,

Table 6 Hydrogen bonding and hydrophobic interactions between chlorogenic acid and amino acid residues within a -glucosidase binding site

\begin{tabular}{|c|c|c|c|c|c|c|c|c|c|c|c|}
\hline 1 & $156 \mathrm{~A}$ & LYS & 3.78 & \multicolumn{2}{|c|}{4839} & \multicolumn{2}{|c|}{1267} & & & & \\
\hline 2 & $158 \mathrm{~A}$ & TYR & 3.56 & \multicolumn{2}{|c|}{4846} & \multicolumn{2}{|c|}{1283} & & & & \\
\hline 3 & $159 \mathrm{~A}$ & PHE & 3.73 & \multicolumn{2}{|c|}{4849} & \multicolumn{2}{|c|}{1296} & & & & \\
\hline \multicolumn{12}{|c|}{ Hydrogen Bonds - } \\
\hline Index & Residue & $\mathrm{AA}$ & \multicolumn{2}{|c|}{ Distance H-A } & Distance & \multicolumn{2}{|c|}{ D-A Donor Angle } & Protein donor? & Sidechain & Donor Atom & Acceptor Atom \\
\hline 1 & $156 \mathrm{~A}$ & LYS & 2.43 & & 3.18 & & 129.09 & $\checkmark$ & $\checkmark$ & $1269[\mathrm{~N} 3+]$ & 4860 [O3] \\
\hline 4 & $315 \mathrm{~A}$ & ARG & 2.20 & & 3.08 & & 147.49 & $\sim$ & $\approx$ & 2557 [Nam] & $4864[0 . c 02]$ \\
\hline 5 & $352 A$ & ASP & 2.18 & & 2.96 & & 135.27 & $x$ & 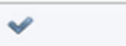 & 4856 [O3] & $2885[0 . c 02]$ \\
\hline 6 & $442 A$ & ARG & 2.51 & & 3.00 & & 110.44 & $\checkmark$ & $\sim$ & $3612[\mathrm{Ng}+]$ & 4854 [O3] \\
\hline
\end{tabular}


Table 7 Hydrogen bonding and hydrophobic interactions between gallic acid and amino acid residues within a-glucosidase binding site

Hydrophobic Interactions ....

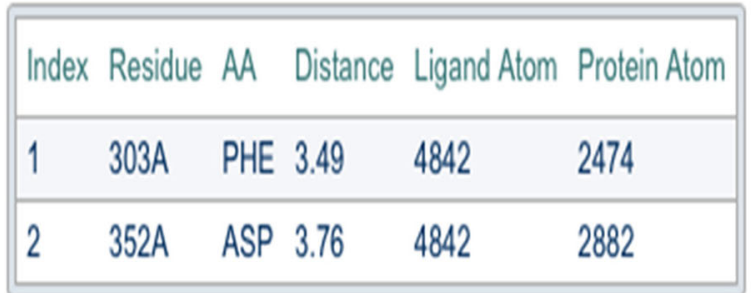

Hydrogen Bonds -

Index Residue AA Distance H-A Distance D-A Donor Angle Protein donor? Sidechain Donor Atom Acceptor Atom

$1315 A \quad$ ARG $2.79 \quad 3.75 \quad 168.90 \quad \times \quad \vee \quad 4847[03] \quad 2564[\mathrm{Ng}+]$

organic anions, and macromolecules (like glucose, water, and amino acids) that are key to neural function as documented by Gupta et al. [14]. The no blood-brain barrier permeability of caffeic acid, gallic acid, quercetin, rutin, chlorogenic acid, kaempferol, and metformin support their non- mutagens and non-carcinogens potentials (Table 3).

Caffeic acid, gallic acid, quercetin, chlorogenic acid, kaempferol, and metformin are non-substrate and noninhibitor of P-glycoprotein (P-gp). Hence, these compounds cannot be acknowledged by the P-gp for any efflux [11]. P-gp is a plasma membrane protein that acts as a localized drug transport mechanism, that energetically distributing drugs out of the cell, therefore they are important proteins involved in xenobiotic efflux. It was only rutin that has the ability as a substrate of $\mathrm{P}$-gp, which implies that P-gp can identify this compound and probably cause its efflux (Table 3). Furthermore, Nisha et al. [18] reported that cytochrome P450 (CYP P450) is a member of microsomal enzymes involved in the metabolism of drugs in the human body system. In this study, the CYP 450 inhibitory profiles were evaluated using CYP1A2, CYP 2C19, CYP 2C9, CYP 2D6 and CYP 3A4. Hence, caffeic acid, metformin (the standard used), rutin and chlorogenic acid demonstrated no inhibitory potential with the possibility of a lower drug-interaction (Table 3 ).

Rutin and kaempferol $(-8.5 \mathrm{kcal} / \mathrm{mol})$, followed by quercetin $(-8.4 \mathrm{kcal} / \mathrm{mol})$, ranked highest in binding affinity with alpha-glucosidase better than that of a standard drug, metformin $(-5.2 \mathrm{kcal} / \mathrm{mol})$ (Table 4). The

Table 8 Hydrogen bonding and hydrophobic interactions between kaemferol and amino acid residues within a-glucosidase binding site

\begin{tabular}{|c|c|c|c|c|c|c|c|c|c|c|c|}
\hline Index & Residue & AA & Distance & \multicolumn{2}{|c|}{ Ligand Atom } & \multicolumn{2}{|c|}{ Protein Atom } & & & & \\
\hline 1 & $158 \mathrm{~A}$ & TYR & 3.45 & \multicolumn{2}{|c|}{4845} & \multicolumn{2}{|c|}{1283} & & & & \\
\hline 2 & 159A & PHE & 3.62 & \multicolumn{2}{|c|}{4853} & \multicolumn{2}{|c|}{1298} & & & & \\
\hline 3 & $178 \mathrm{~A}$ & PHE & 3.42 & \multicolumn{2}{|c|}{4848} & \multicolumn{2}{|c|}{1459} & & & & \\
\hline 4 & $178 \mathrm{~A}$ & PHE & 3.72 & \multicolumn{2}{|c|}{4852} & \multicolumn{2}{|c|}{1457} & & & & \\
\hline 5 & 216A & VAL & 3.22 & \multicolumn{2}{|c|}{4849} & \multicolumn{2}{|c|}{1769} & & & & \\
\hline \multicolumn{12}{|c|}{ Hydrogen Bonds -} \\
\hline Index & Residue & AA & \multicolumn{2}{|c|}{ Distance H-A } & Distance & D-A & Donor Angle & Protein donor? & Sidechain & Donor Atom & Acceptor Atom \\
\hline 1 & 215A & ASP & 1.93 & & 2.90 & & 171.25 & $\approx$ & $\checkmark$ & 4854 [O3] & $1763[0 . c 02]$ \\
\hline 2 & $315 A$ & ARG & 2.52 & & 3.40 & & 148.89 & $\approx$ & $\sim$ & $4858[03]$ & $2564[\mathrm{Ng}+]$ \\
\hline 3 & $352 A$ & ASP & 2.35 & & 2.70 & & 100.23 & $x$ & $\sim$ & 4856 [O3] & $2885[0 . c 02]$ \\
\hline 4 & $411 \mathrm{~A}$ & GLU & 3.28 & & 3.79 & & 113.91 & $x$ & $\sim$ & $4860[\mathrm{O} 3]$ & $3358[0 . c 02]$ \\
\hline 5 & $442 \mathrm{~A}$ & ARG & 3.75 & & 4.09 & & 103.85 & $\sim$ & $\sim$ & $3612[\mathrm{Ng}+]$ & 4837 [O2] \\
\hline
\end{tabular}


Table 9 Hydrogen bonding and hydrophobic interactions between quercetin and amino acid residues within a-glucosidase binding site

\begin{tabular}{|llllll|}
\hline \multicolumn{1}{|l}{ Hydrophobic Interactions ..... } \\
\begin{tabular}{|llllll|}
\hline 1 & Residue & AA & Distance & Ligand Atom & Protein Atom \\
\hline 2 & 158 A & TYR & 3.54 & 4845 & 1285 \\
\hline 3 & 178 A & PHE & 3.51 & 4852 & 1296 \\
\hline
\end{tabular}
\end{tabular}

\begin{tabular}{|c|c|c|c|c|c|c|c|c|c|}
\hline Index & Residue & $A A$ & Distance H-A & Distance D-A & Donor Angle & Protein donor? & Sidechain & Donor Atom & Acceptor Atom \\
\hline 1 & $215 A$ & ASP & 3.24 & 4.07 & 143.41 & $x$ & $\checkmark$ & 4854 [O3] & $1763[0 . c 02]$ \\
\hline 2 & $279 \mathrm{~A}$ & GLN & 2.78 & 3.37 & 119.17 & $\checkmark$ & $\checkmark$ & 2275 [Nam] & $4837[\mathrm{O} 2]$ \\
\hline 3 & $280 A$ & HIS & 2.06 & 2.99 & 158.19 & $x$ & $\checkmark$ & 4862 [O3] & 2285 [N2] \\
\hline 4 & $315 \mathrm{~A}$ & ARG & 2.70 & 3.04 & 100.64 & $\nu$ & $\checkmark$ & $2566[\mathrm{Ng}+]$ & $4860[\mathrm{O} 3]$ \\
\hline 5 & $352 \mathrm{~A}$ & ASP & 2.97 & 3.64 & 127.35 & $x$ & $\checkmark$ & $4858[\mathrm{O} 3]$ & $2885[0 . c 02]$ \\
\hline
\end{tabular}

II-Stacking .........

\begin{tabular}{|llllllll|}
\hline \hline Index & Residue & AA & Distance & Angle & Offset & Type & Ligand Atoms \\
\hline 1 & $303 \mathrm{~A}$ & PHE & 5.23 & 63.38 & 1.94 & T & $4839,4840,4844,4845,4846,4847$ \\
\hline 2 & $303 \mathrm{~A}$ & PHE & 4.97 & 63.11 & 1.08 & T & $4837,4839,4840,4841,4842,4843$ \\
\hline
\end{tabular}

interactions of these compounds were stabilized by hydrogen bonding and hydrophobic interaction. During the docking simulation of alpha-glucosidase with the selected bioactive compounds from Senecio biafrae, eleven residues within the active site of alpha-glucosidase (Ser157, Tyr158, Ser240, His280, Asp307, Lue313, Arg315, Asp352, Asn415, Arg442) were intricate in hydrogen bond formation with rutin, five residues within the active site of alpha-glucosidase (Asp215, Arg315, Asp352, Glu411, Arg442) were saliently involved in hydrogen bond formation with kaemferol while amino acids (Asp215, Gln279, His280, Arg315, Asp352) were important in hydrogen bond formation with quercetin (Figs. 1, 2, 3, 4, 5, 6 and 7). Hydrophobic interactions

Table 10 Hydrogen bonding and hydrophobic interactions between rutin and amino acid residues within a-glucosidase binding site

\begin{tabular}{|c|c|c|c|c|c|c|c|c|c|c|c|}
\hline Index & Residue & AA & Distance & \multicolumn{7}{|c|}{ Distance Ligand Atom Protein Atom } & \\
\hline 1 & $158 \mathrm{~A}$ & TYR & 3.87 & \multicolumn{2}{|c|}{$\begin{array}{l}\text { Ligand Atom } \\
4838\end{array}$} & \multicolumn{2}{|c|}{1285} & & & & \\
\hline 2 & $159 \mathrm{~A}$ & PHE & 3.21 & \multicolumn{2}{|c|}{4852} & 1296 & & & & & \\
\hline 3 & $178 \mathrm{~A}$ & PHE & 3.19 & \multicolumn{2}{|c|}{4852} & \multicolumn{2}{|c|}{1459} & & & & \\
\hline 4 & $303 \mathrm{~A}$ & PHE & 2.53 & \multicolumn{2}{|c|}{4847} & \multicolumn{2}{|c|}{2474} & & & & \\
\hline 5 & $315 A$ & ARG & 3.69 & \multicolumn{2}{|c|}{4863} & \multicolumn{2}{|c|}{2561} & & & & \\
\hline \multicolumn{12}{|c|}{ Hydrogen Bonds -} \\
\hline Index & Residue & AA & \multicolumn{2}{|c|}{ Distance $\mathrm{H}-\mathrm{A}$} & Distance & D-A & Donor Angle & Protein donor? & Sidechain & Donor Atom & Acceptor Atom \\
\hline 1 & $157 \mathrm{~A}$ & SER & 2.78 & & 3.66 & & 148.98 & $\approx$ & $\approx$ & $4880[03]$ & $1273[\mathrm{O} 2]$ \\
\hline 2 & $158 \mathrm{~A}$ & TYR & 2.64 & & 3.24 & & 119.47 & $x$ & $x$ & $4865[03]$ & 1279 [O2] \\
\hline 3 & $240 A$ & SER & 2.91 & & 3.83 & & 156.28 & $x$ & $\sim$ & 4882 [03] & 1949 [O3] \\
\hline 4 & $280 A$ & HIS & 2.83 & & 3.23 & & 105.52 & $\approx$ & $\sim$ & 4888 [O3] & 2285 [N2] \\
\hline 5 & $307 \mathrm{~A}$ & ASP & 1.90 & & 2.54 & & 120.59 & $x$ & $\sim$ & 4869 [O3] & $2505[0 . c 02]$ \\
\hline 6 & $313 \mathrm{~A}$ & LEU & 3.17 & & 3.97 & & 139.42 & $x$ & $x$ & 4884 [O3] & 2541 [O2] \\
\hline 7 & $315 A$ & ARG & 2.64 & & 3.19 & & 115.77 & $\sim$ & $\sim$ & $2566[\mathrm{Ng}+]$ & 4869 [O3] \\
\hline 8 & $315 A$ & ARG & 2.55 & & 3.41 & & 145.83 & $\sigma$ & $x$ & 2557 [Nam] & 4867 [03] \\
\hline 9 & $352 A$ & ASP & 1.93 & & 2.81 & & 148.30 & $x$ & $\sim$ & 4855 [O3] & $2885[0 . c 02]$ \\
\hline 10 & $415 A$ & ASN & 2.06 & & 2.87 & & 137.79 & $\sim$ & $\sim$ & 3393 [Nam] & 4865 [03] \\
\hline 11 & $442 A$ & ARG & 2.07 & & 2.91 & & 142.18 & 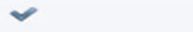 & $\sim$ & $3612[\mathrm{Ng}+]$ & 4857 [O3] \\
\hline
\end{tabular}


Table 11 Hydrogen bonding and hydrophobic interactions between metformin and amino acid residues within a- glucosidase binding site

\begin{tabular}{|c|c|c|c|c|c|c|c|c|c|}
\hline \multicolumn{10}{|c|}{ Hydrogen Bonds - } \\
\hline Index & Residue & AA & Distance $\mathrm{H}$ & H-A Distance D-A & Donor Angle & Protein donor? $\mathrm{s}$ & Sidechain & Donor Atom & Acceptor Atom \\
\hline 1 & $213 A$ & ARG & 3.28 & 4.05 & 136.97 & $\checkmark$ & $\checkmark$ & $1746[\mathrm{Ng}+]$ & $4839[\mathrm{Ng}+]$ \\
\hline 2 & $213 A$ & ARG & 2.41 & 3.39 & 175.25 & $\checkmark$ & $\checkmark$ & $1747\left[\mathrm{Ng}^{+}\right]$ & $4839[\mathrm{Ng}+]$ \\
\hline 3 & $351 \mathrm{~A}$ & HIS & 3.29 & 4.04 & 138.86 & $x$ & $\checkmark$ & $4839[\mathrm{Ng}+]$ & 2877 [N2] \\
\hline \multicolumn{10}{|c|}{ $\pi$-Cation Interactions .... } \\
\hline Index & Residue & AA & Distance & Offset Protein cha & arged? Ligand & Group Ligand At & Atoms & & \\
\hline 1 & $72 A$ & TYR & 5.11 & 1.18 & guanidi & 4837,483 & 838,4839 & & \\
\hline \multicolumn{10}{|c|}{ Salt Bridges .... } \\
\hline Index & Residue & AA & Distance & Protein positive? L & Ligand Group & Ligand Atoms & & & \\
\hline 1 & $215 A$ & ASP & 5.49 & $x$ & Guanidine & $4838,4840,4841$ & & & \\
\hline 2 & $215 A$ & ASP & 3.79 & $x$ & Guanidine & $4837,4838,4839$ & & & \\
\hline 3 & $277 \mathrm{~A}$ & GLU & 4.22 & $x$ & Guanidine & $4838,4840,4841$ & & & \\
\hline 4 & $277 A$ & GLU & 3.53 & $x$ & Guanidine & $4837,4838,4839$ & & & \\
\hline 5 & $352 A$ & ASP & 4.73 & $x$ & Guanidine & $4838,4840,4841$ & & & \\
\hline 6 & $352 \mathrm{~A}$ & ASP & 3.85 & $x$ & Guanidine & $4837,4838,4839$ & & & \\
\hline
\end{tabular}

also contributed to the interaction of rutin with amino acid residues (Tyr158, Phe159, Phe178, Phe303, Arg315), kaempferol with amino acid residues (Tyr158, Phe159, Phe178, Val216) and quercetin with amino acid residue (Tyr158, Phe159, Phe178) within the active site of alphaglucosidase (Tables 5, 6, 7, 8, 9, 10 and 11). Therefore, inhibition of alpha-glucosidase by rutin, kaempferol, and quercetin is a potent target for effective anti-diabetes drug design as it effectively checkmates the level of blood glucose.
Alpha-amylase is an enzyme that hydrolyzes alpha bonds of large, alpha-linked polysaccharides, such as starch and glycogen, yielding glucose and maltose that hydrolyzes alpha bonds of large, alpha-linked polysaccharides, such as starch and glycogen, yielding glucose and maltose (Gaspar et al., [13]). It is the major form of amylase found in humans and other mammals. Alpha -amylases are enzymes that hydrolyze starch molecules to give diverse products including dextrins and progressively smaller polymers composed of glucose units

Table 12 Hydrogen bonding and hydrophobic interactions between caffeic acid and amino acid residues within a-amylase binding site

\begin{tabular}{|llllll|}
\hline \multicolumn{1}{|l}{ Hydrophobic Interactions } &... & & \\
\hline Index & Residue & AA & Distance & Ligand Atom & Protein Atom \\
\hline 1 & 58 A & TRP & 3.58 & 3942 & 470 \\
\hline 2 & $62 A$ & TYR & 3.65 & 3946 & 510 \\
\hline 3 & $165 A$ & LEU & 3.84 & 3947 & 1300 \\
\hline
\end{tabular}

\begin{tabular}{|c|c|c|c|c|c|c|c|c|c|}
\hline Index & Residue & AA & Distance H-A & Distance D-A & Donor Angle & Protein donor? & Sidechain & Donor Atom & Acceptor Atom \\
\hline 1 & $63 \mathrm{~A}$ & GLN & 2.43 & 3.14 & 129.13 & $\approx$ & $\sim$ & $3950[0 . c 02]$ & $525[\mathrm{O} 2]$ \\
\hline 2 & $195 \mathrm{~A}$ & ARG & 2.35 & 3.33 & 174.80 & $\checkmark$ & $\diamond$ & $1543[\mathrm{Ng}+]$ & 3954 [O3] \\
\hline 3 & $197 \mathrm{~A}$ & ASP & 2.18 & 2.82 & 121.77 & $x$ & 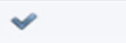 & 3954 [O3] & $1558[0 . c 02]$ \\
\hline 4 & $198 \mathrm{~A}$ & ALA & 3.69 & 4.02 & 102.44 & $\checkmark$ & $\boldsymbol{x}$ & 1560 [Nam] & 3952 [O3] \\
\hline
\end{tabular}

II-Stacking $\ldots . . . . .$.

\begin{tabular}{|lllllllll|}
\hline Index & Residue & AA & Distance & Angle & Offset & Type & Ligand Atoms \\
\hline 1 & $62 A$ & TYR & 4.38 & 17.00 & 1.44 & P & $3940,3941,3942,3943,3944,3945$ \\
\hline
\end{tabular}


Table 13 Hydrogen bonding and hydrophobic interactions between chlorogenic acid and amino acid residues within a-amylase binding site

\begin{tabular}{|c|c|c|c|c|c|c|c|c|c|c|c|}
\hline Index & Residue & $A A$ & Distance & \multicolumn{2}{|c|}{ Ligand Atom } & \multicolumn{2}{|c|}{ Protein Atom } & & & & \\
\hline 1 & $58 \mathrm{~A}$ & TRP & 3.80 & 395 & & 470 & & & & & \\
\hline 2 & $59 \mathrm{~A}$ & TRP & 3.72 & 394 & & 479 & & & & & \\
\hline 3 & $62 \mathrm{~A}$ & TYR & 3.67 & 395 & & 511 & & & & & \\
\hline 4 & $62 \mathrm{~A}$ & TYR & 3.46 & 394 & & 510 & & & & & \\
\hline \multicolumn{12}{|c|}{ Hydrogen Bonds -} \\
\hline Index & Residue & AA & Distance & $\mathrm{H}-\mathrm{A}$ & Distance & D-A & Donor Angle & Protein donor? & Sidechain & Donor Atom & Acceptor Atom \\
\hline 1 & $163 \mathrm{~A}$ & THR & 2.06 & & 3.02 & & 173.06 & $\checkmark$ & $\checkmark$ & $1288[\mathrm{O} 3]$ & 3966 [0.co2] \\
\hline 2 & $163 \mathrm{~A}$ & THR & 3.25 & & 3.87 & & 122.53 & x & $\checkmark$ & 3969 [03] & $1288[\mathrm{O} 3]$ \\
\hline 3 & $195 \mathrm{~A}$ & ARG & 2.21 & & 3.01 & & 137.87 & $\checkmark$ & $\checkmark$ & $1543[\mathrm{Ng}+]$ & 3959 [O3] \\
\hline 4 & $197 \mathrm{~A}$ & ASP & 2.98 & & 3.73 & & 134.26 & $*$ & $\checkmark$ & 3957 [O3] & $1558[0 . c 02]$ \\
\hline 5 & $233 \mathrm{~A}$ & GLU & 2.09 & & 3.00 & & 154.46 & $x$ & $\checkmark$ & 3959 [O3] & 1853 [O-] \\
\hline
\end{tabular}

Table 14 Hydrogen bonding and hydrophobic interactions between gallic acid and amino acid residues within a -amylase binding site

\begin{tabular}{l|llllll|}
\hline \multicolumn{1}{l}{ Hydrophobic Interactions } &.... & & \\
\hline
\end{tabular}

\begin{tabular}{|c|c|c|c|c|c|c|c|c|c|}
\hline Index & Residue & AA & Distance $\mathrm{H}-\mathrm{A}$ & Distance D-A & Donor Angle & Protein donor? & Sidechain & Donor Atom & Acceptor Atom \\
\hline 1 & $59 \mathrm{~A}$ & TRP & 2.16 & 2.90 & 130.41 & * & $x$ & 3948 [0.co2] & 475 [O2] \\
\hline 2 & $197 \mathrm{~A}$ & ASP & 2.61 & 3.53 & 156.25 & $x$ & $v$ & 3952 [O3] & $1558[0 . c 02]$ \\
\hline
\end{tabular}

$\pi$-Stacking .........

Index Residue AA Distance Angle Offset Type Ligand Atoms

$1 \quad 62 A \quad$ TYR $4.72 \quad 19.44 \quad 1.96 \quad \mathrm{P} \quad 3940,3941,3942,3943,3944,3945$

Table 15 Hydrogen bonding and hydrophobic interactions between kaempferol and amino acid residues within a -amylase binding site

Hydrophobic Interactions $\ldots . .$.
\begin{tabular}{|llllll|}
\hline Index & Residue & AA & Distance & Ligand Atom & Protein Atom \\
\hline 1 & 58A & TRP & 3.70 & 3956 & 470 \\
\hline 2 & 59A & TRP & 3.76 & 3950 & 482 \\
\hline 3 & 62A & TYR & 3.58 & 3956 & 511 \\
\hline
\end{tabular}

\begin{tabular}{|c|c|c|c|c|c|c|c|c|c|}
\hline Index & Residue & AA & Distance $\mathrm{H}-\mathrm{A}$ & Distance D-A & Donor Angle & Protein donor? & Sidechain & Donor Atom & Acceptor Atom \\
\hline 1 & $195 \mathrm{~A}$ & ARG & 3.38 & 4.07 & 128.81 & $\checkmark$ & $\checkmark$ & $1542[\mathrm{Ng}+]$ & 3957 [O3] \\
\hline 2 & $195 \mathrm{~A}$ & ARG & 2.14 & 3.12 & 168.68 & $\checkmark$ & $\checkmark$ & $1543[\mathrm{Ng}+]$ & 3957 [O3] \\
\hline 3 & $233 \mathrm{~A}$ & GLU & 2.40 & 3.21 & 138.87 & x & $\checkmark$ & 3957 [O3] & $1852[\mathrm{O} 3]$ \\
\hline
\end{tabular}

II-Stacking ........

\begin{tabular}{|llllllll|}
\hline Index & Residue & AA & Distance & Angle & Offset & Type & Ligand Atoms \\
\hline 1 & 59A & TRP & 3.91 & 3.11 & 1.49 & P & $3942,3943,3947,3948,3949,3950$ \\
\hline
\end{tabular}


Table 16 Hydrogen bonding and hydrophobic interactions between quercetin and amino acid residues within a-amylase binding site

\begin{tabular}{l|lllll|}
\hline \multicolumn{1}{l}{ Hydrophobic Interactions } &.... & & \\
\hline Index & Residue & AA & Distance & Ligand Atom & Protein Atom \\
\hline 1 & 58A & TRP & 3.66 & 3956 & 470 \\
\hline 2 & 59A & TRP & 3.75 & 3950 & 482 \\
\hline
\end{tabular}

\begin{tabular}{|c|c|c|c|c|c|c|c|c|c|}
\hline Index & Residue & $A A$ & Distance $\mathrm{H}-\mathrm{A}$ & Distance D-A & Donor Angle & Protein donor? & Sidechain & Donor Atom & Acceptor Atom \\
\hline 1 & $59 \mathrm{~A}$ & TRP & 2.77 & 3.69 & 157.40 & $x$ & $\sim$ & 3965 [O3] & 480 [N2] \\
\hline 2 & $195 \mathrm{~A}$ & ARG & 3.15 & 3.82 & 127.21 & $\checkmark$ & $\checkmark$ & $1542[\mathrm{Ng}+]$ & 3959 [03] \\
\hline 3 & $195 \mathrm{~A}$ & ARG & 1.91 & 2.89 & 170.36 & $\checkmark$ & $\vee$ & $1543[\mathrm{Ng}+]$ & 3959 [O3] \\
\hline 4 & $233 \mathrm{~A}$ & GLU & 2.22 & 3.02 & 137.88 & $x$ & $\vartheta$ & 3959 [O3] & 1853 [O-] \\
\hline
\end{tabular}

\begin{tabular}{|llllllll|}
\hline Index & Residue & AA & Distance & Angle & Offset & Type & Ligand Atoms \\
\hline 1 & $59 A$ & TRP & 4.01 & 3.95 & 1.68 & P & $3942,3943,3947,3948,3949,3950$ \\
\hline 2 & $62 A$ & TYR & 4.60 & 25.41 & 1.73 & P & $3951,3952,3953,3954,3955,3956$ \\
\hline
\end{tabular}

Table 17 Hydrogen bonding and hydrophobic interactions between rutin and amino acid residues within a-amylase binding site

\begin{tabular}{|c|c|c|c|c|c|}
\hline Index & Residue & AA & Distance & Ligand Atom & Protein Atom \\
\hline 1 & $59 \mathrm{~A}$ & TRP & 3.78 & 3950 & 477 \\
\hline 2 & $162 \mathrm{~A}$ & LEU & 3.88 & 3966 & 1282 \\
\hline 3 & $165 \mathrm{~A}$ & LEU & 3.60 & 3955 & 1300 \\
\hline 4 & $235 \mathrm{~A}$ & ILE & 3.50 & 3980 & 1868 \\
\hline
\end{tabular}

Hydrogen Bonds -

\begin{tabular}{|c|c|c|c|c|c|c|c|c|c|}
\hline Index & Residue & AA & Distance H-A & Distance D-A & Donor Angle & Protein donor? & Sidechain & Donor Atom & Acceptor Atom \\
\hline 1 & $63 \mathrm{~A}$ & GLN & 3.25 & 3.83 & 119.16 & $x$ & $\checkmark$ & 3960 [03] & 525 [02] \\
\hline 2 & $151 \mathrm{~A}$ & TYR & 3.58 & 4.08 & 115.97 & $\checkmark$ & $\checkmark$ & 1194 [03] & 3975 [03] \\
\hline 3 & $197 \mathrm{~A}$ & ASP & 3.04 & 3.59 & 116.13 & $x$ & $\checkmark$ & 3968 [03] & 1558 [0.co2] \\
\hline 4 & $300 \mathrm{~A}$ & ASP & 2.32 & 2.73 & 103.63 & $x$ & $\checkmark$ & 3972 [03] & 2388 [0-] \\
\hline
\end{tabular}

Table 18 Hydrogen bonding and hydrophobic interactions between metformin and amino acid residues within a-amylase binding site

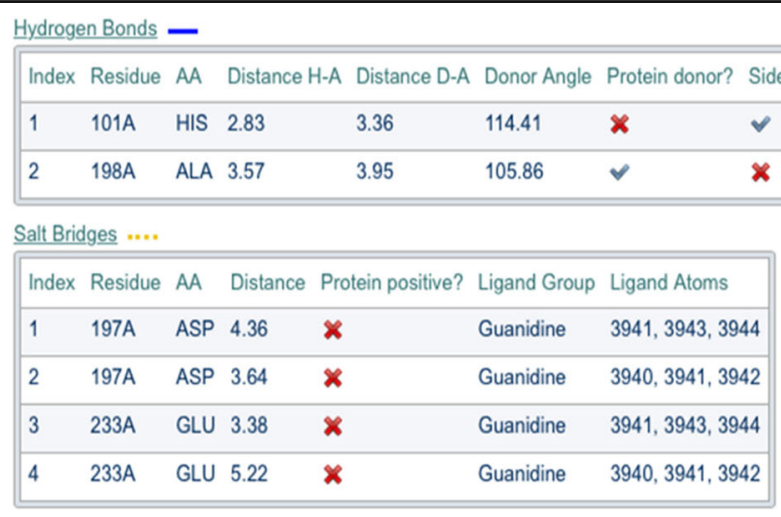




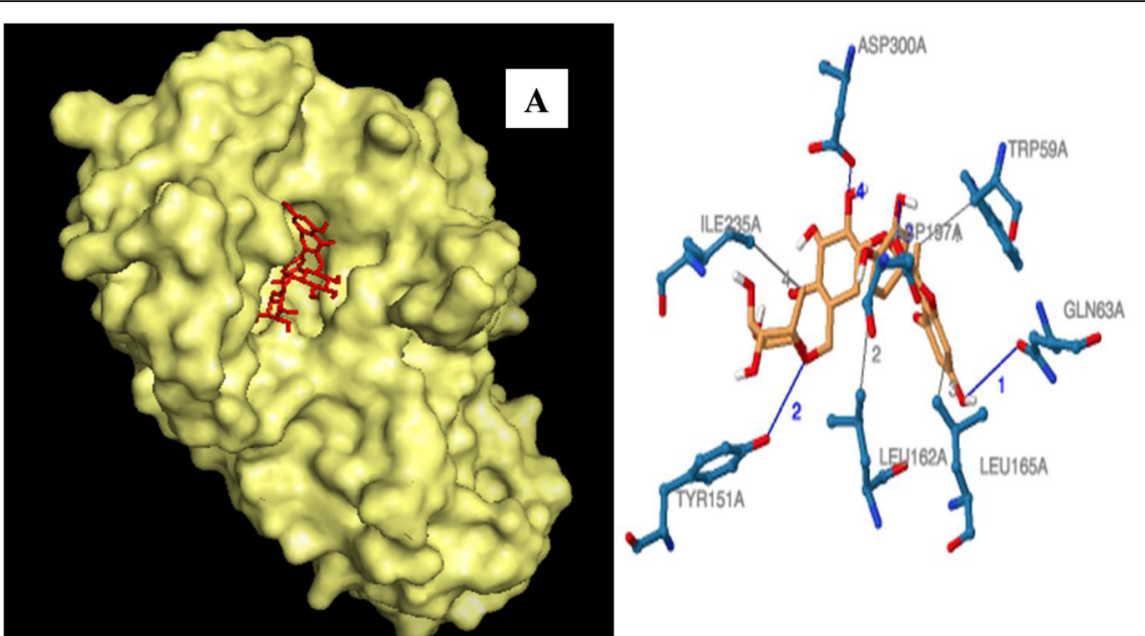

Fig. 13 Binding pose and binding site of rutin with a-amylase (panel A), molecular interaction of rutin with amino acid residues within the binding pocket of the protein structure (panel B)

which causes hyperglycemia and development of type II diabetes mellitus [2]. Rutin $(-8.2 \mathrm{kcal} / \mathrm{mol})$, quercetin $(-8.2 \mathrm{kcal} / \mathrm{mol})$ and $\mathrm{kaempferol}(-8.1 \mathrm{kcal} / \mathrm{mol})$ exhibited better interaction by showing more binding affinity with alpha-amylase than the standard drug metformin $(-4.5 \mathrm{kcal} / \mathrm{mol}$ ) (Table 4$)$ and this interaction was stabilized and sustained by hydrophobic interaction and hydrogen bonding. Gln63, Tyr151, Asp197, Asp300 are important residues for hydrogen bonding when rutin interacted with $\alpha$-amylase. While Trp59, Arg195, Glu233 were very germane for the formation of hydrogen bonding when quercetin interacted with $\alpha$-amylase, Arg195 and Glu233 were also very important residues for hydrogen bonding when kaempferol interacted with $\alpha$-amylase (Figs. 8, 9, 10, 11, 12, 13 and 14). Residues (Trp59, Lue162, Lue165, Ile235), (Trp58, Trp59) and (Trp58, Trp59, Tyr62), were responsible for hydrophobic interaction when $\alpha$ -
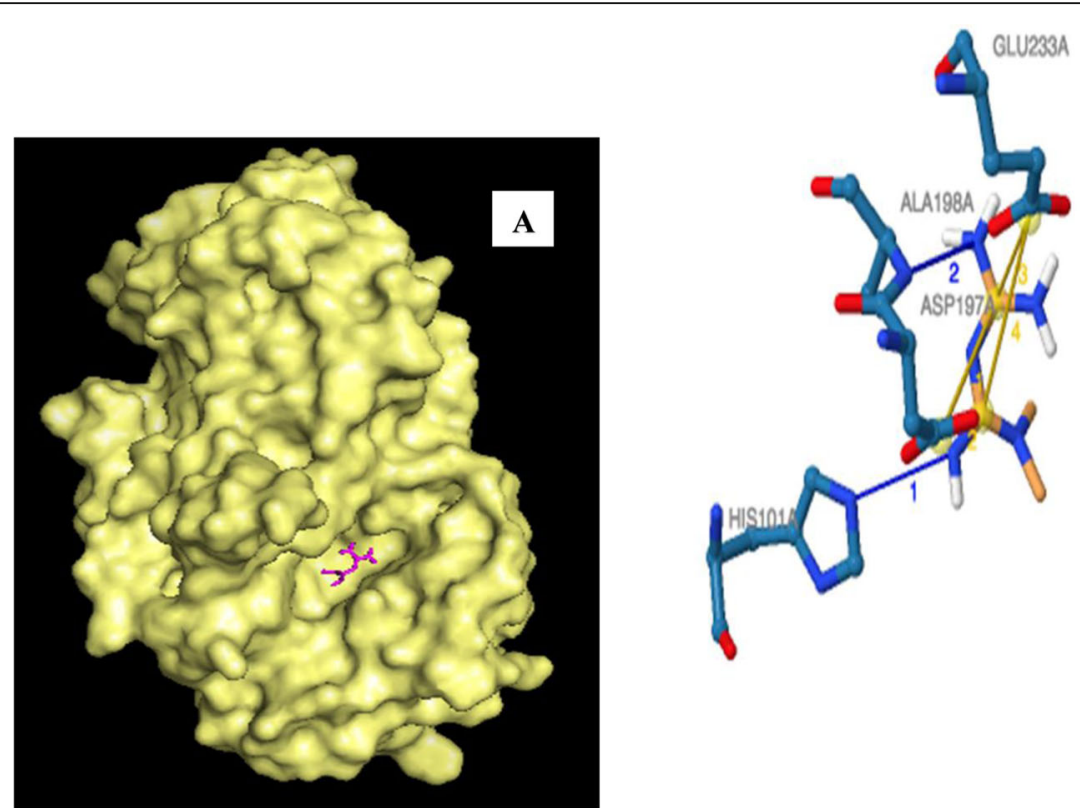

B

Fig. 14 Binding pose and binding site of metformin with a-amylase (panel A), molecular interaction of metformin with amino acid residues within the binding pocket of the protein structure (panel B) 
amylase interacted with rutin, quercetin, and kaempferol respectively (Table 12, 13, 14, 15, 16, 17 and 18). Hence, the inhibition of alpha-amylase by rutin, quercetin, and kaemferol is implicative of their vast anti-diabetic abilities and thus, a potent alternative for synthetic drugs.

\section{Conclusion}

From the results obtained in this study, it can be deduced that the bioactive compounds used especially caffeic acid was the only compound that obeys Lipinski's rule of five, good ADMET results, although ranked 4th in binding affinity against $\alpha$-glucosidase and 5 th in binding affinity against $\alpha$-amylase may be a promising therapeutic agent than the metformin in the management of type II diabetes mellitus. In another word, compounds that can also be applicable as a potent alternative drug in the management of type II diabetes mellitus are quercetin and kaempferol, they obey Lipinski's rule of five, slightly poor ADMET results and they have high binding affinity against both alpha-glucosidase and alpha-amylase while rutin only has good binding affinity but does not obey Lipinski's rule of five and slightly bad ADMET profiles.

\section{Acknowledgments}

No acknowledgments.

\section{Author's contributions}

This is a single-author manuscript, so everything about this manuscript was done by BOA. The author read and approved the final manuscript.

\section{Funding}

Not applicable.

\section{Availability of data and materials}

The datasets used and/or analysed during the current study are available from the corresponding author on reasonable request.

\section{Declarations}

Ethics approval and consent to participate Not applicable.

\section{Consent for publication}

Not applicable.

\section{Competing interests}

The authors declare that they have no competing interests.

Received: 1 June 2020 Accepted: 30 December 2021

Published online: 24 January 2022

\section{References}

1. Adefegha SA, Oboh G. Antioxidant and inhibitory properties of Clerodendrum volubile leaf extracts on key enzymes relevant to non-insulin dependent diabetes mellitus and hypertension. J Taibah Univer Med Sci. 2015;10(4):521-33. https://doi.org/10.1016/j.jtusci.2015.10.008.

2. Agarwal P, Gupta R. Alpha-amylase inhibition can treat diabetes mellitus. Res Rev J Med Health Sci. 2016;5:1-8.

3. Ajiboye BO, Edobor G, Ojo AO, Onikanni SA, Olaranwaju Ol, Muhammad NO. Effect of aqueous leaf extract of Senecio biafrae on hyperglycaemic and serum lipid profile of alloxan-induced diabetic rats. Inter J Dis Disord. 2014; 2(11):059-64.
4. Ajiboye BO, Ibukun EO, Edobor G, Ojo OA, Onikanni SA. Qualitative and quantitative analysis of phytochemicals in Senecio biafrae leaf. Inter J Pharma Sci and Res. 2013;1(5):428-32.

5. Ajiboye BO, Ojo OA, Okesola MA, Akinyemi AJ, Talabi JY, Idowu OT, et al. In vitro antioxidant activities and inhibitory effects of phenolic extract of Senecio biafrae (Oliv and Hiern) against key enzymes linked with type II. diabetes mellitus and Alzheimer's disease. Food Sci Nut. 2018;6(7):1803-10. https://doi.org/10.1002/fsn3.749.

6. Ajiboye BO, Oyinloye BE, Agboinghale PE, Onikanni SA, Asogwa E, Kappo AP. Antihyperglycaemia and related gene expressions of aqueous extract of Gongronema latifolium leaf in alloxan-induced diabetic rats. Pharm Biol. 2019;57(1):604-11. https://doi.org/10.1080/13880209.2019.1657907.

7. Alqahtani AS, Hidayathulla S, Rehman MT, ElGamal AA, Al-Massarani S, Razmovski-Naumovski V, et al. Alpha-Amylase and Alpha-Glucosidase Enzyme Inhibition and Antioxidant Potential of 3-Oxolupenaland Katononic Acid Isolated from Nuxia oppositifolia. Biom. 2020;10(1):61. https://doi.org/1 0.3390/biom10010061.

8. Coleman RL, Scott CA, Lang Z, Bethel MA, Tuomilehto J, Holman RR. Metaanalysis of the impact of alpha-glucosidase inhibitors on incident diabetes and cardiovascular outcomes. Cardiovasc Diabe. 2019;18(1):135. https://doi. org/10.1186/s12933-019-0933-y.

9. Daneman R, Prat A. The Blood-Brain Barrier. Cold Spring Harb Perspect Biol. 2015;7(1):a020412.

10. Derosa G, Maffioli P. Mini-special issue paper management of diabetic patients with hypoglycemic agents a-glucosidase inhibitors and their use in clinical practice. Arch Med Sci. 2012;5(5):899-906. https://doi.org/10.5114/aoms.2012.31621.

11. Elekofehinti OO, Ejelonu OC, Kamdem JP, Akinlosotu OB, Famuti A, Adebowale $D D$, et al. Discovery of potential visfatin activators using in silico docking and ADME predictions as therapy for type 2 diabetes. Beni-Suef Univ J Bas App Sci. 2018;2018(2):241-9. https://doi.org/10.1016/j.bjbas.2018.02.007.

12. Etsassala NGR, Badmus JA, Waryo TT, Marnewick JL, Cupido CN, Hussein AA, et al. Alpha-glucosidase and alpha-amylase inhibitory activities of novel Abietane Diterpenes from Salvia africana-lutea. Antioxidants. 2019;8(10):421. https://doi.org/10.3390/antiox8100421.

13. Gaspar PM, Ewing E. Feasibility and usability of salivary alpha-amylase to measure stress among individuals with dementia. Res Gerontol Nurs. 2019; 13(3):120-4. https://doi.org/10.3928/19404921-20191025-02.

14. Gupta S, Dhanda S, Sandhir R. Anatomy and physiology of blood-brain barrier. Brain Targeted Drug Deliv Syst Els. 2019;2019:7-31. https://doi.org/1 0.1016/B978-0-12-814001-7.00002-0.

15. Johnson OO, Adeyemi DK, Adeusi O, Ayoola GA. Evaluation of the phytochemical constituents and antioxidant activity of the stem of Senecio biafrae (Asteraceae). Niger J Pharma Appl Sci Res. 2017;6(2):19-23.

16. Li Y, Ding Y. Minireview: therapeutic potential of myricetin in diabetes mellitus. Food Sci Human Wellness. 2012;1(1):19-25. https://doi.org/10.1016/ j.fshw.2012.08.002.

17. Lipinski CA. Lead- and drug-like compounds: the rule-of-five revolution. Drug Discov Today Technol. 2004;1(4):337-41. https://doi.org/10.1016/j. ddtec.2004.11.007.

18. Nisha CM, Kumar A, Vimal A, Bai BM, Pal D, Kumar A. Docking and ADMET prediction of few GSK-3 inhibitors divulges 6-bromoindirubin-3-oxime as a potential inhibitor. J Mol Grap Model. 2016;65:100-7. https://doi.org/10.101 6/j.jmgm.2016.03.001.

19. Oboh G. Antioxidant properties of some commonly consumed and underutilized tropical legumes. Europ Food Res Technol. 2006;224(1):61-5. https://doi.org/10.1007/s00217-006-0289-x.

20. Ojo OA, Afon AA, Ojo AB, Ajiboye BO, Oyinloye BE, Kappo AP. Inhibitory effects of solvent-partitioned fractions of two Nigerian herbs (Spondias mombin Linn. And Mangifera indica L.) on a-amylase and a-glucosidase. Antioxidants. 2018; 7(6):73. https://doi.org/10.3390/antiox7060073.

21. Oyinloye BE, Adekiya TA, Aruleba RT, Ojo OA, Ajiboye BO. Structure-based docking studies of GLUT4 towards exploring selected phytochemicals from Solanum xanthocarpum as a therapeutic target for the treatment of Cancer. Curr Drug DiscoTechnol. 2019;16(4):406-16. https://doi.org/10.2174/1570163 815666180801152110.

22. Papatheodorou K, Papanas N, Banach M, Papazoglou D, Edmonds M. Complications of diabetes 2016. J Diab Res. 2016;2016:1-3. https://doi.org/1 0.1155/2016/6989453.

23. Sivasothy $Y$, Loo KY, Leong KH, Litaudon M, Awang K. A potent alphaglucosidase inhibitor from Myristica cinnamomea king. Phyto. 2016;122:2659. https://doi.org/10.1016/j.phytochem.2015.12.007. 
24. Unuofin JO, Lebelo SL. Antioxidant effects and mechanisms of medicinal plants and their bioactive compounds for the prevention and treatment of type 2 diabetes: an updated review. Oxid Med Cell Longev. 2020;2020:36. https://doi.org/10.1155/2020/1356893.

\section{Publisher's Note}

Springer Nature remains neutral with regard to jurisdictional claims in published maps and institutional affiliations.

Submit your manuscript to a SpringerOpen ${ }^{\circ}$ journal and benefit from:

- Convenient online submission

- Rigorous peer review

- Open access: articles freely available online

- High visibility within the field

- Retaining the copyright to your article

Submit your next manuscript at $\boldsymbol{\sim}$ springeropen.com 